Machseh Lajesoumim 



\title{
Machseh Lajesoumim
}

\author{
AJewish Orphanage in the City of Leiden \\ 1890-1943
}

Jaap W. Focke

Foreword by Prof. Dan Michman

Head of the International Institute for Holocaust Research at Yad Vashem, Jerusalem

Incorporating unpublished data provided by W.F. van Zegveld ( $\dagger$ ) and L.P. Kasteleyn

Photographic restoration by F. Hoek ( $\dagger$ ) 
This publication was made possible with support from the Vereniging Centraal Israëlitisch Wees- en Doorgangshuis Machseh Lajesoumiem.

\author{
Cover design: Coördesign, Leiden \\ Typesetting: Crius Group, Hulshout \\ ISBN $\quad 9789463726955$ \\ e-ISBN $\quad 9789048553877$ (pdf) \\ DOI $\quad 10.5117 / 9789463726955$ \\ NUR 688
}

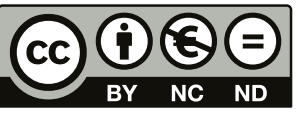

Creative Commons - Attribution Non-Commercial No Derivatives (CC BY NC ND)

This licence allows redistribution of verbatim copies of the works only. This licence is often called the "free advertising" licence because it allows others to download the works and share them with others as long as they mention the author and link back to the author, but they cannot change them in any way or use them commercially or to create derivative works.

For more information about Creative Commons licences see: https://creativecommons.org.

(C) The author / Amsterdam University Press B.V., Amsterdam 2021 

Machseh Lajesoumim (Refuge for orphans) was the name shown on the new building, above the front doors, partly visible on the photograph on the back cover. Its official name, which adorned the old building on Stille Rijn (Fig. 2.1), was "Centraal Israëlitisch Wees- en Doorgangshuis", that is, National Jewish Orphanage and Transit Home.

This book is dedicated to the memory of the children and stafff of the Jewish Orphanage in Leiden who perished in the Holocaust.

Alleenlijk wacht $u$, en bewaart uw ziel wel, dat gij niet vergeet de dingen, die uw ogen gezien hebben; en dat zij niet van uw hart wijken, al de dagen uws levens; en gij zult ze aan uw kinderen en uw kindskinderen bekend maken. ${ }^{1}$

Only take heed to thyself, and keep thy soul diligently, lest thou forget the things which thine eyes have seen, and lest they depart from thy heart all the days of thy life: but teach them thy sons, and thy sons' sons. ${ }^{2}$

Deut. 4:9

1 Statenvertaling.

2 King James. 


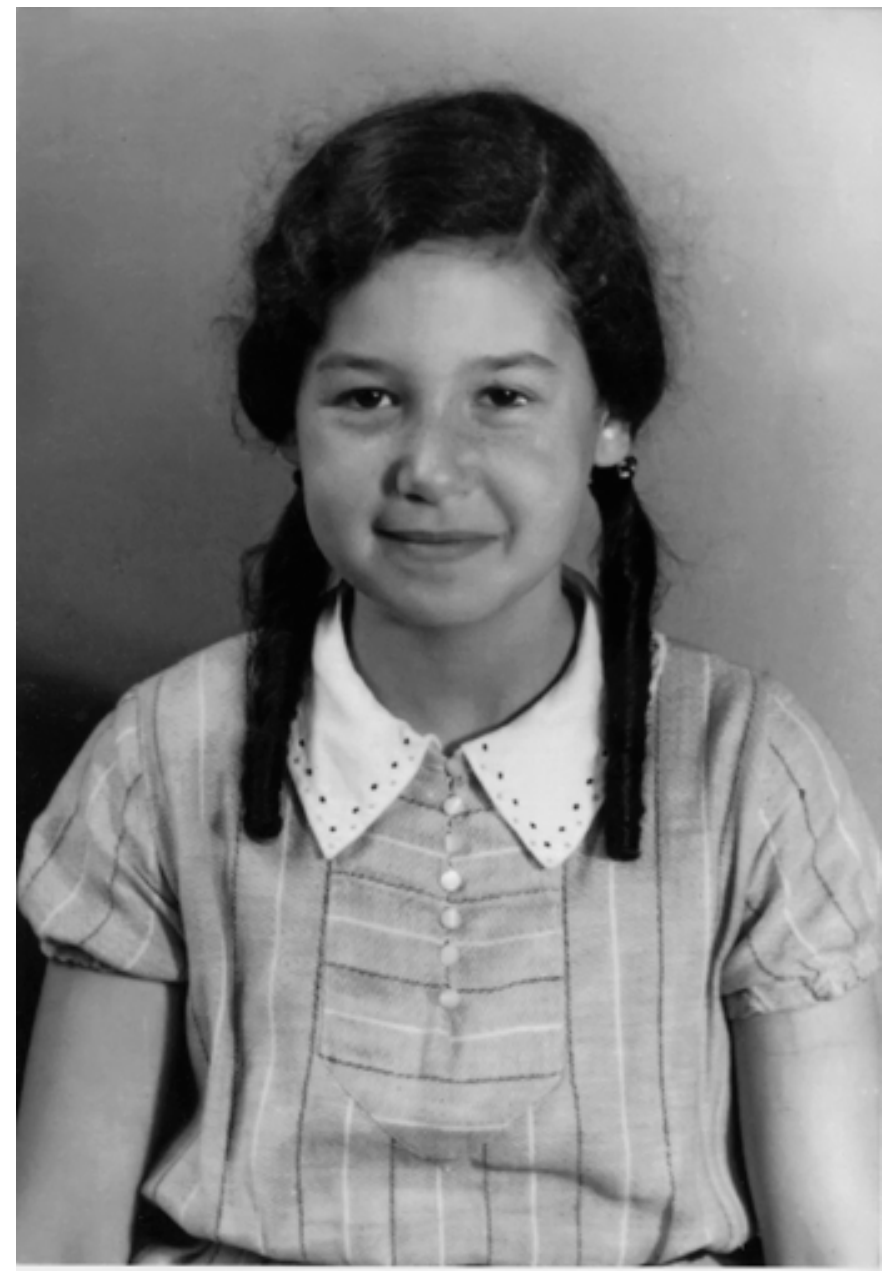

Lotte Adler

Frankfurt, $8^{\text {th }}$ February 1925-Sobibor, 26 ${ }^{\text {th }}$ March 1943

Photograph taken in Frankfurt am Main (Germany) in 1937 when she was

12 years old

Lotte's father was arrested in 1937 and killed in KL Buchenwald on $3^{\text {rd }}$ July 1938. After Kristallnacht ( $9^{\text {th }} / 10^{\text {th }}$ November 1938) her mother sent

Lotte and her younger sister Henny to safety in Holland by train with the Kindertransport of $22^{\text {nd }}$ November 1938. They were taken in by the orphanage in Leiden that same night.

But the Germans caught up with them when they invaded Holland in May 1940. 
